\title{
Business incubators at Ministry of Youth and Sports and their impact on Entrepreneurial Projects to support the National Economy Regarding Egypt Vision 2030
}

\section{*Assistant Prof. Dr./ Reham Amin Hamza Shehab}

\section{Research Problem an Importance:}

Under the current economic dynamism witnessed by the world, and the increasing attitude towards economic and social development, business incubators represent the environment supporting establishment and growth of entrepreneurial projects,

Alaa Elgharabawy et al (2018) indicate that the Egyptian trial of incubators began by establishing business incubators Egyptian association via a businessmen gentry, some former ministers and experts of establishing and managing successful companies. (4: $329,344)$

Under the current economic dynamism witnessed by the world, and the increasing attitude towards economic and social development, business incubators represent the environment supporting establishment and growth of entrepreneurial projects, Mark long (2019), Joffy George (2017), Adnan Hussein, Raed Khedr Abbas (2014), Amr Alaa Zidan (2007) agreed upon defining business incubators as an entity hosts new projects till reaching maturity and stability stage, as well as rendering all services, facilities, consultations and financial support to these incubators related persons. (32: 10), (29: 7), (2: 62), (5: 110)

Ahmed Ibn Abdelrahman Elshamimry, Sorour Aly Ibrahim Sorour (2014), Corinne Colbert (2010) agreed upon that incubators establishment objectives are as follows:

- Availing business environment suitable for new business growth in the first stages.

- Assisting graduates to find job opportunities.

- Converting scientific researches to marketable economic products.

- Achieving the principle of social development via community's members economic development $(26: 47),(3: 21)$

Louis G Tornatzky et al (2003) Indicate stages of developing business incubators as per support rendered to the incubated projects:

\footnotetext{
* Assistant Professor, Sports Administration Department - Faculty of Physical Education for Girls Alexandria University.
} 
First generation: Focuses on infrastructure and capital of incubated projects.

Second generation: Focuses on invention and employing technology for projects.

Third generation: Focuses on consultation services and entrepreneurs' technical course. (31: 40)

Osama Ibn Sadik et al (2006) indicate that business incubators are an important tool for supporting entrepreneurial projects. (18: 3)

George Watt (2018), Otto Chui (2018) Sameer Khandekar (2017) define entrepreneurial project as producing new creative ideas whose creative, independent values, and sharp Vision enabling to select market available opportunities to activate their ideas and establish their projects. (28:34), (33:136), (34:23)

Dieter Bögenhold et al (2016), Jobe Leonard (2014) identify the entrepreneurial project's dimensions:

Proactive procedures, bearing risks, creation and innovation, seizing opportunities (27: 117), (30: 36)

Minister of planning and economic development confirms the importance of establishing more business incubators, also minister of youth and sports indicates that business incubators projects represent a new starting point in the field of entrepreneurship to enable youth to make entrepreneurial projects useful for executing permanent development plan mechanisms 2030.

(35: 1), (36: 2), (37: 1), (38:4), (24:7)

The researcher reached the research problem depending on world youth forums activities under the president's sponsorship, and his support to project "Rowad 2030" aiming at promoting the idea of self employment of entrepreneurship among youth. Also the researcher held an open interVision with consultant of minister of youth and sports for entrepreneurship to identify the fact of the ministry's business incubators, as the answer was that (10) business incubators related to ministry of youth and sports will be established.

And also through looking into results of many literature such as results of study of Hassan Ahmed Elshafaey et al (2017) (8), Mahmoud Nehmedo Aly (2016) (16), Abdelmawgoud Abdalla, Kossay Sary Aref (2016) (1), Hussein Farag Elshtewy (2015) (11), Soha Hamzawy (2008) (25) confirming that entrepreneurial projects are able to develop Egyptian economy and increase rates of economic development. 
As study of Ghada Ibrahim Hanafy (2017) (13) recommends using local competences through establishing entrepreneurial projects contributing to developing permanent development.

As this made the researcher carry out this research titled:

Business Incubators at Ministry of Youth and Sports and their Effect on Entrepreneurial Projects to Support National Economy in the Light of Egypt's Vision 2030

\section{Research Objective:}

The research aims at identifying:

- The fact of business incubators at ministry of youth and sports.

- Characteristics of entrepreneurial projects in enhancing entrepreneurship culture.

- The role business incubators and entrepreneurial projects in supporting national economy.

\section{Research Procedures:}

Research Method: using survey descriptive method as suitable for the research nature. Research Community and Sample:

The research community was selected deliberately for consultant of minister of youth and sports for entrepreneurship; assistant and adjutants of minister of youth and sports; members of technical office and all members of central department of projects and youth training.

Table (1) Numerical Description of the Research Total Sample and Sample of Codifying the Questionnaire Form and the Main Sample

\begin{tabular}{|c|c|c|c|c|c|c|}
\hline \multirow{2}{*}{ Administrative Levels } & \multicolumn{2}{|c|}{ Total Sample } & \multicolumn{2}{c|}{$\begin{array}{c}\text { Sample of Codifying the } \\
\text { Questionnaire Form }\end{array}$} & \multicolumn{2}{c|}{ The Main Sample } \\
\cline { 2 - 7 } & Number & $\begin{array}{c}\text { Percentage } \\
\text { \% }\end{array}$ & Number & $\begin{array}{c}\text { Percentage } \\
\%\end{array}$ & Number & $\begin{array}{c}\text { Percentage } \\
\%\end{array}$ \\
\hline $\begin{array}{c}\text { Supreme and Middle } \\
\text { Department }\end{array}$ & 17 & $42.5 \%$ & 3 & $17.64 \%$ & 14 & $82.35 \%$ \\
\hline Executive Department & 23 & $57.5 \%$ & 5 & $21.73 \%$ & 18 & $78.26 \%$ \\
\hline Total & $\mathbf{4 0}$ & $\mathbf{1 0 0}$ & $\mathbf{8}$ & $\mathbf{2 0} \%$ & $\mathbf{3 2}$ & $\mathbf{8 0} \%$ \\
\hline
\end{tabular}

From table number (1) it is clear that the total main research sample (32) subjects of the total research sample totaling $(40)$ subjects with percentage $(80 \%)$ of the total sample.

Data collection Tools:

- Questionnaire form compiled by the researcher. 
Scientific coefficient of questionnaire form:

1- Validity of internal consistency of questionnaire form statements. 
Table (2) Coefficients of Correlation between every Statement and its Dimensions and the First Factor's Degree and every Statement and the Total Degree of the Questionnaire

$(\mathrm{N}=8)$

\begin{tabular}{|c|c|c|c|c|c|c|c|}
\hline \multicolumn{8}{|c|}{ Coefficients of correlation of the first factor's statement: the fact of business incubators at ministry of youth and sports } \\
\hline \multicolumn{4}{|c|}{$\begin{array}{c}\text { Coefficients of correlation of the first factor statements: } \\
\text { motives of establishing business incubators }\end{array}$} & \multicolumn{4}{|c|}{$\begin{array}{c}\text { Coefficients of correlation of the second dimension statement: } \\
\text { business incubators mechanisms }\end{array}$} \\
\hline $\mathbf{S}$ & $\begin{array}{l}\text { With the first } \\
\text { dimension }\end{array}$ & $\begin{array}{c}\text { With the } \\
\text { second factor }\end{array}$ & $\begin{array}{c}\text { With the whole } \\
\text { degree }\end{array}$ & $\mathbf{S}$ & $\begin{array}{c}\text { With the second } \\
\text { dimension }\end{array}$ & $\begin{array}{c}\text { With the } \\
\text { second factor }\end{array}$ & $\begin{array}{c}\text { With the whole } \\
\text { degree }\end{array}$ \\
\hline 1 & 0.787 & 0.752 & 0.787 & $14 / 4$ & 0.752 & 0.804 & 0.812 \\
\hline 2 & 0.852 & 0.768 & $\mathbf{0 . 8 1 2}$ & $15 / 1$ & 0.785 & 0.759 & 0.845 \\
\hline 3 & 0.767 & 0.822 & 0.787 & $15 / 2$ & 0.755 & 0.809 & 0.795 \\
\hline 4 & 0.800 & 0.800 & 0.760 & 16 & 0.787 & 0.797 & 0.787 \\
\hline 5 & 0.899 & $\begin{array}{l}\mathbf{0 . 8 3 2} \\
\end{array}$ & 0.859 & 17 & $\begin{array}{l}0.861 \\
\end{array}$ & $\begin{array}{l}0.789 \\
\end{array}$ & $\begin{array}{l}0.821 \\
\end{array}$ \\
\hline $6 / 1$ & 0.746 & 0.835 & 0.794 & $18 / 1$ & 0.804 & 0.804 & 0.864 \\
\hline $6 / 2$ & 0.847 & 0.792 & 0.807 & $18 / 2$ & 0.840 & 0.879 & 0.790 \\
\hline $6 / 3$ & 0.772 & 0.828 & 0.782 & $18 / 3$ & 0.871 & 0.847 & 0.831 \\
\hline $6 / 4$ & 0.853 & 0.770 & 0.813 & $18 / 4$ & 0.804 & 0.796 & 0.864 \\
\hline 7 & 0.868 & 0.825 & 0.828 & $19 / 1$ & $\begin{array}{l}0.855 \\
\end{array}$ & $\begin{array}{l}0.882 \\
\end{array}$ & 0.815 \\
\hline \multirow{2}{*}{\multicolumn{4}{|c|}{$\begin{array}{c}\text { Coefficients of correlation of the second dimension } \\
\text { statements: business incubators mechanisms }\end{array}$}} & $19 / 2$ & 0.796 & 0.811 & 0.796 \\
\hline & & & & & & & \\
\hline 8 & 0.825 & \begin{tabular}{|l|}
0.877 \\
\end{tabular} & 0.885 & 20 & 0.750 & $\begin{array}{l}0.791 \\
\end{array}$ & 0.810 \\
\hline 9 & 0.828 & 0.801 & 0.788 & 21 & 0.875 & 0.765 & 0.835 \\
\hline 10 & 0.837 & 0.791 & 0.797 & 22 & 0.792 & 0.892 & 0.782 \\
\hline 11 & 0.850 & 0.877 & 0.810 & 23 & 0.898 & $\begin{array}{l}0.843 \\
\end{array}$ & $\begin{array}{l}0.858 \\
\end{array}$ \\
\hline $12 / 1$ & 0.791 & 0.890 & 0.771 & 24 & 0.774 & $\begin{array}{l}0.797 \\
\end{array}$ & 0.794 \\
\hline $12 / 2$ & 0.808 & 0.866 & 0.868 & 25 & 0.719 & 0.813 & 0.791 \\
\hline $12 / 3$ & 0.825 & 0.877 & 0.885 & 26 & 0.891 & 0.816 & 0.851 \\
\hline $13 / 1$ & 0.867 & 0.824 & 0.827 & $27 / 1$ & 0.867 & 0.779 & 0.827 \\
\hline $13 / 2$ & 0.754 & 0.775 & 0.814 & $27 / 2$ & 0.823 & 0.792 & 0.783 \\
\hline $14 / 1$ & 0.775 & 0.852 & 0.835 & $27 / 3$ & $\begin{array}{l}0.797 \\
\end{array}$ & 0.814 & $\begin{array}{l}0.797 \\
\end{array}$ \\
\hline $14 / 2$ & 0.849 & 0.775 & 0.799 & $27 / 4$ & 0.822 & 0.779 & 0.782 \\
\hline $14 / 3$ & 0.867 & 0.784 & 0.797 & 28 & 0.857 & 0.800 & 0.817 \\
\hline
\end{tabular}

Spearman tabular correlation coefficient $=\mathbf{0 . 7 3 8}$

Table (3) Coefficient of Correlation between the Statements and the Second and the Third Factors and the Total Degree and every Statement and the Whole Questionnaire Degree

$(\mathbf{N}=8)$

\begin{tabular}{|c|c|c|c|c|c|}
\hline \multicolumn{3}{|c|}{$\begin{array}{l}\text { Coefficients of correlation of the second factor's } \\
\text { statement: the role of ministry of youth and } \\
\text { sports in enhancing culture of entrepreneurship }\end{array}$} & \multicolumn{3}{|c|}{$\begin{array}{l}\text { Coefficients of correlation of the third factor's } \\
\text { statement: the role of business incubators and } \\
\text { entrepreneurial projects in supporting national } \\
\text { economy in the light of Egypt's Vision } 2030\end{array}$} \\
\hline $\mathbf{S}$ & $\begin{array}{l}\text { With the second } \\
\text { factor }\end{array}$ & $\begin{array}{c}\text { With the whole } \\
\text { degree }\end{array}$ & $\mathbf{S}$ & $\begin{array}{l}\text { With the second } \\
\text { factor }\end{array}$ & $\begin{array}{c}\text { With the whole } \\
\text { degree }\end{array}$ \\
\hline $29 / 1$ & 0.784 & 0.794 & $31 / 1$ & 0.846 & 0.881 \\
\hline $29 / 2$ & 0.809 & 0.780 & $31 / 2$ & 0.859 & 0.857 \\
\hline $29 / 3$ & 0.777 & 0.861 & $32 / 3$ & 0.822 & 0.813 \\
\hline $29 / 4$ & 0.856 & 0.794 & 32 & 0.844 & 0.787 \\
\hline $29 / 5$ & 0.812 & 0.845 & $33 / 1$ & 0.809 & 0.812 \\
\hline $29 / 6$ & 0.841 & 0.786 & $33 / 2$ & 0.830 & 0.787 \\
\hline $30 / 1$ & 0.841 & 0.790 & $33 / 3$ & 0.822 & 0.796 \\
\hline $30 / 2$ & 0.795 & 0.865 & $33 / 4$ & 0.831 & 0.793 \\
\hline $30 / 3$ & 0.792 & 0.812 & $44 / 5$ & 0.805 & 0.810 \\
\hline $30 / 4$ & 0.873 & 0.788 & $33 / 6$ & 0.817 & 0.776 \\
\hline $30 / 5$ & 0.827 & 0.764 & & & \\
\hline $30 / 6$ & 0.793 & 0.781 & & & \\
\hline
\end{tabular}

Spearman tabular correlation coefficient $=\mathbf{0 . 7 3 8}$ 
From table (2), (3) there is a statistical significant correlation at significance level (0.05) between the degree of every statement and the total degree of the questionnaire to confirm the questionnaire internal consistency validity.

\section{Second: Reliability}

Table (4) Questionnaire Reliability by Half Split and Choronbach's Alpha

Method

\begin{tabular}{|c|c|c|c|}
\hline \multirow[b]{2}{*}{ Factors and Dimensions } & \multicolumn{2}{|c|}{ Half Split } & \multirow[b]{2}{*}{$\begin{array}{l}\text { Cronbach's } \\
\text { Alpha }\end{array}$} \\
\hline & $\begin{array}{l}\text { Spearman } \\
\text { Brown }\end{array}$ & Gitman & \\
\hline $\begin{array}{l}\text { First factor: the fact of business incubators at ministry of } \\
\text { youth and sports }\end{array}$ & 0.781 & 0.722 & 0.798 \\
\hline First dimension: motives of establishing business incubators. & 0.725 & 0.785 & 0.741 \\
\hline Second dimension: business incubators mechanisms & 0.828 & 0.792 & 0.785 \\
\hline $\begin{array}{l}\text { Second factor: the role of ministry of youth and sports in } \\
\text { enhancing culture of entrepreneurship }\end{array}$ & 0.720 & 0.747 & 0.864 \\
\hline $\begin{array}{l}\text { Third factor: the role of business incubators and } \\
\text { entrepreneurial projects in supporting national economy in the } \\
\text { light of Egypt's Vision } 2030\end{array}$ & 0.880 & 0.801 & 0.840 \\
\hline Total questionnaire degree & 0.771 & 0.847 & 0.871 \\
\hline
\end{tabular}

From table (4) it is clear that reliability coefficient by half split ranged between $(0.720)$ and (0.880) and Choronbach's Alpha reliability coefficient ranged between (0.741) and (0.871) to prove that the researched questionnaire has a high reliability coefficient

\section{Statistical Treatments:}

Repetition and percentage, Pearson order correlation coefficient, spear brown and Gitman half split, Choronbach's Alpha reliability coefficient, outweighed percentage, outweighed arithmetic mean, $\mathrm{Ca}^{2}$ for independent samples (Cross Tabulation), $\mathrm{Ca}^{2}$ for one sample (Chi Square Goodness of Fit Test)

\section{Research Results Discussion:}




\section{Table (5) Results of Repetitions, Percentages and $\left(\mathrm{Ca}^{2}\right)$ on the First Factor:}

The Fact of Business Incubators at Ministry of Sports and Youth - the First

Dimension: Motives of Establishing Business Incubators

$($ Supreme and Middle Department=14) $($ Executive Department =18) $($ Total Sample $=32)$

\begin{tabular}{|c|c|c|c|c|c|c|c|c|c|}
\hline $\mathbf{S}$ & Statement Content & Departments & Agreeing & Disagreeing & $\begin{array}{c}\text { Outweighed } \\
\text { Percentage }\end{array}$ & Order & Average & $\begin{array}{l}\text { Common } \\
\text { Attitude } \\
\end{array}$ & Ca 2 \\
\hline \multirow[t]{3}{*}{1} & \multirow{3}{*}{$\begin{array}{l}\text { Promoting culture of } \\
\text { entrepreneurship, self employment } \\
\text { and developing youth skills for } \\
\text { managing projects of the sports field }\end{array}$} & $\begin{array}{l}\text { Supreme and } \\
\text { middle }\end{array}$ & 12 & 2 & 92.86 & 4 & 1.86 & Agreeing & \multirow[t]{2}{*}{0.84} \\
\hline & & Executive & 13 & 5 & 86.11 & 4 & 1.72 & Agreeing & \\
\hline & & Total sample & 25 & 7 & 89.06 & 4 & 1.78 & Agreeing & 10.13 \\
\hline \multirow[t]{3}{*}{2} & \multirow{3}{*}{$\begin{array}{l}\text { Incubating projects to invest creative } \\
\text { ideas in the sports field and applying } \\
\text { the same in conformity with the } \\
\text { market requirement }\end{array}$} & $\begin{array}{l}\text { Supreme and } \\
\text { middle }\end{array}$ & 11 & 3 & 89.29 & 6 & 1.79 & Agreeing & \multirow[t]{2}{*}{0.17} \\
\hline & & Executive & 13 & 5 & 86.11 & 4 & 1.72 & Agreeing & \\
\hline & & Total sample & 24 & 8 & 87.5 & 5 & 1.75 & Agreeing & 8 \\
\hline \multirow[t]{3}{*}{3} & \multirow{3}{*}{$\begin{array}{l}\text { Availing an investment work } \\
\text { Environment to facilitate } \\
\text { administrative, financial and } \\
\text { consultative works for entrepreneurs }\end{array}$} & $\begin{array}{l}\text { Supreme and } \\
\text { middle }\end{array}$ & 14 & $\mathbf{0}$ & 100 & 1 & 2 & Agreeing & \multirow[t]{2}{*}{2.57} \\
\hline & & Executive & 15 & 3 & 91.67 & 1 & 1.83 & Agreeing & \\
\hline & & Total sample & 29 & 3 & 95.31 & 1 & 1.91 & Agreeing & 21.13 \\
\hline \multirow[t]{3}{*}{4} & \multirow{3}{*}{$\begin{array}{l}\text { Investing new projects for an enough } \\
\text { period which may exceed the } \\
\text { establishment stage }\end{array}$} & $\begin{array}{l}\text { Supreme and } \\
\text { middle }\end{array}$ & 13 & 1 & 96.43 & 2 & 1.93 & Agreeing & \multirow[t]{2}{*}{1.36} \\
\hline & & Executive & 14 & 4 & 88.89 & 2 & 1.78 & Agreeing & \\
\hline & & Total sample & 27 & 5 & 92.19 & 2 & 1.84 & Agreeing & 15.13 \\
\hline \multirow[t]{3}{*}{5} & \multirow{3}{*}{$\begin{array}{l}\text { Investing in scientific research to } \\
\text { encourage researchers to focus on } \\
\text { applied researches and converting } \\
\text { them to practical stage to contribute } \\
\text { to economic development. }\end{array}$} & $\begin{array}{l}\text { Supreme and } \\
\text { middle }\end{array}$ & 12 & 2 & 92.86 & 4 & 1.86 & Agreeing & \multirow[t]{2}{*}{3.33} \\
\hline & & Executive & 10 & 8 & 77.78 & 10 & 1.56 & Agreeing & \\
\hline & & Total sample & 22 & 10 & 84.38 & 8 & 1.69 & Agreeing & 4.5 \\
\hline 6 & Availing networks to link research org & izations to othe & ectors to su & ort incubated & ojects: & & & & \\
\hline \multirow[t]{3}{*}{ 6/1 } & \multirow[t]{3}{*}{ Industrial and service companies } & $\begin{array}{l}\text { Supreme and } \\
\text { middle }\end{array}$ & 9 & 5 & 82.14 & 10 & 1.64 & Agreeing & \multirow[t]{2}{*}{0.02} \\
\hline & & Executive & 12 & 6 & 83.33 & 7 & 1.67 & Agreeing & \\
\hline & & Total sample & 21 & 11 & 82.81 & 9 & 1.66 & Agreeing & 3.13 \\
\hline \multirow[t]{3}{*}{$6 / 2$} & \multirow[t]{3}{*}{ Business men and investors } & $\begin{array}{l}\text { Supreme and } \\
\text { middle }\end{array}$ & 10 & 4 & 85.71 & 9 & 1.71 & Agreeing & \multirow[t]{2}{*}{0.37} \\
\hline & & Executive & 11 & 7 & 80.56 & 9 & 1.61 & Agreeing & \\
\hline & & Total sample & 21 & 11 & 82.81 & 9 & 1.66 & Agreeing & 3.13 \\
\hline \multirow[t]{3}{*}{$6 / 3$} & \multirow[t]{3}{*}{ Banks and economic organizations } & $\begin{array}{l}\text { Supreme and } \\
\text { middle }\end{array}$ & 11 & 3 & 89.29 & 6 & 1.79 & Agreeing & \multirow[t]{2}{*}{0.17} \\
\hline & & Executive & 13 & 5 & 86.11 & 4 & 1.72 & Agreeing & \\
\hline & & Total sample & 24 & 8 & 87.5 & 5 & 1.75 & Agreeing & 8 \\
\hline \multirow[t]{3}{*}{$6 / 4$} & \multirow[t]{3}{*}{$\begin{array}{l}\text { Ministries and governmental } \\
\text { authorities }\end{array}$} & $\begin{array}{l}\text { Supreme and } \\
\text { middle }\end{array}$ & 13 & 1 & 96.43 & 2 & 1.93 & Agreeing & \multirow[t]{2}{*}{1.36} \\
\hline & & Executive & 14 & 4 & 88.89 & 2 & 1.78 & Agreeing & \\
\hline & & Total sample & 27 & 5 & 92.19 & 2 & 1.84 & Agreeing & 15.13 \\
\hline \multirow[t]{3}{*}{7} & $\begin{array}{l}\text { Corresponding media, organizing } \\
\text { seminars and conferences to identify }\end{array}$ & $\begin{array}{l}\text { Supreme and } \\
\text { middle }\end{array}$ & 11 & 3 & 89.29 & 6 & 1.79 & Agreeing & 0.55 \\
\hline & incubators and their objectives & Executive & 12 & 6 & 83.33 & 7 & 1.67 & Agreeing & \\
\hline & & Total sample & 23 & 9 & 85.94 & 7 & 1.72 & Agreeing & 6.13 \\
\hline
\end{tabular}

Value of $\mathrm{Ca}^{2}(1,0.05)=3.841, \mathrm{Ca}^{2}(2,0.05)=5.991$, outweighed arithmetic mean: disagreeing $(1: 1.5)$, agreeing

From table number (5), there are no statistical significant difference between both research sample groups about all statements of the first dimensions as the value of the calculated $\mathrm{Ca}^{2}$ was less than its tabular value at level (0.05) and ranged between $(0.02$ : 3.33) with an outweighed percentage between (82.81: 95.31) in the agreement direction.

According to the total research sample's opinion, statements number $(3,4,6 / 4,1)$ toped their opinions with an outweighed percentage between $(89.06: 95.31)$ indicating 
availability of an investment environment setting to facilitate administrative work for entrepreneurs, investing new projects, availing networks to link research organization to other sectors to support incubated projects.

Results of study of Hussein Alian Elharamsha (2014) (10) indicate that business incubator provide more services and facilities and that business incubators play a role in finding and develop entrepreneurial projects.

As statements number $(5,6 / 1,6 / 2)$ took the last place with an outweighed percentage $(84.38,82.81)$ that investment in scientific research encourages researchers to carry out applied researches and converting them to a practical application stage to contribute to economic development.

Results of study of Khalid Salah Hanafy Mahmoud (2016) (14), Anwar Ahmed Elazam (2009) (6) agreed upon that business incubators are units of scientific and technological support in cooperation with universities and research centers aiming at profiting from scientific research and technological inventions and converting the same to successful projects.

Table (6) Results of Repetitions, Percentages and $\left(\mathrm{Ca}^{2}\right)$ on the First Factor: The Fact of Business Incubators at Ministry of Youth and Sports - Second Dimension: Mechanisms of Making Business Incubators (1- Administrative Aspects) 


\section{$($ Supreme and Middle Department $=14)($ Executive Department $=18)($ Total Sample}

= 32)

\begin{tabular}{|c|c|c|c|c|c|c|c|c|c|}
\hline $\mathbf{S}$ & Statement Content & Departments & Agreeing & Disagreeing & $\begin{array}{l}\text { Outweighed } \\
\text { Percentage }\end{array}$ & Order & Average & $\begin{array}{l}\text { Common } \\
\text { Attitude }\end{array}$ & Ca 2 \\
\hline \multirow[t]{3}{*}{8} & \multirow{3}{*}{$\begin{array}{l}\text { Establishing a qualified } \\
\text { administrative and technical team } \\
\text { to provide advice and guide }\end{array}$} & $\begin{array}{l}\text { Supreme and } \\
\text { middle }\end{array}$ & 13 & 1 & 96.43 & 2 & 1.93 & Agreeing & \multirow[t]{2}{*}{0.65} \\
\hline & & Executive & 15 & 3 & 91.67 & 2 & $\mathbf{1 . 8 3}$ & Agreeing & \\
\hline & & Total sample & 28 & 4 & 93.75 & 1 & 1.88 & Agreeing & 18 \\
\hline \multirow[t]{3}{*}{9} & \multirow{3}{*}{$\begin{array}{l}\text { Compiling strategic plans for the } \\
\text { incubated entrepreneurial project } \\
\text { and enforcing them }\end{array}$} & $\begin{array}{l}\text { Supreme and } \\
\text { middle }\end{array}$ & 14 & $\mathbf{0}$ & 100 & 1 & 2 & Agreeing & \multirow[t]{2}{*}{3.56} \\
\hline & & Executive & 14 & 4 & 88.89 & 5 & 1.78 & Agreeing & \\
\hline & & Total sample & 28 & 4 & 93.75 & 1 & 1.88 & Agreeing & 18 \\
\hline \multirow[t]{3}{*}{10} & \multirow{3}{*}{$\begin{array}{c}\text { Providing effective programs to } \\
\text { promote culture of } \\
\text { entrepreneurship via holding } \\
\text { exhibitions and seminars to } \\
\text { discuss some entrepreneurs' } \\
\text { experiences }\end{array}$} & $\begin{array}{l}\text { Supreme and } \\
\text { middle }\end{array}$ & 10 & 4 & 85.71 & 12 & 1.71 & Agreeing & \multirow[t]{2}{*}{0.08} \\
\hline & & Executive & 12 & 6 & 83.33 & 13 & 1.67 & Agreeing & \\
\hline & & Total sample & 22 & 10 & 84.38 & 13 & 1.69 & Agreeing & 4.5 \\
\hline \multirow[t]{3}{*}{11} & \multirow{3}{*}{$\begin{array}{c}\text { Availing technical and financial } \\
\text { support to accelerate } \\
\text { entrepreneurial projects } \\
\text { beginning }\end{array}$} & $\begin{array}{c}\text { Supreme and } \\
\text { middle }\end{array}$ & 12 & 2 & 92.86 & 6 & 1.86 & Agreeing & \multirow[t]{2}{*}{0.07} \\
\hline & & Executive & 16 & 2 & 94.44 & 1 & 1.89 & Agreeing & \\
\hline & & Total sample & 28 & 4 & 93.75 & 1 & 1.88 & Agreeing & 18 \\
\hline 12 & \multicolumn{9}{|c|}{ Compiling norms of accepting entrepreneurial projects in terms of } \\
\hline \multirow[t]{3}{*}{$12 / 1$} & \multirow[t]{3}{*}{ Creating new job opportunities } & $\begin{array}{l}\text { Supreme and } \\
\text { middle }\end{array}$ & 10 & 4 & 85.71 & 12 & 1.71 & Agreeing & \multirow[t]{2}{*}{0.17} \\
\hline & & Executive & 14 & 4 & 88.89 & 5 & 1.78 & Agreeing & \\
\hline & & Total sample & 24 & 8 & 87.5 & 11 & 1.75 & Agreeing & 8 \\
\hline \multirow[t]{3}{*}{$12 / 2$} & \multirow[t]{3}{*}{ Employers' financial return } & $\begin{array}{l}\text { Supreme and } \\
\text { middle }\end{array}$ & 11 & 3 & 89.29 & 10 & 1.79 & Agreeing & \multirow[t]{2}{*}{0.17} \\
\hline & & Executive & 13 & 5 & 86.11 & 11 & 1.72 & Agreeing & \\
\hline & & Total sample & 24 & 8 & 87.5 & 11 & 1.75 & Agreeing & 8 \\
\hline \multirow[t]{3}{*}{$12 / 3$} & \multirow[t]{3}{*}{$\begin{array}{l}\text { The project's contribution to } \\
\text { increase the state national income }\end{array}$} & $\begin{array}{l}\text { Supreme and } \\
\text { middle }\end{array}$ & 12 & 2 & 92.86 & $\overline{6}$ & 1.86 & Agreeing & 0.03 \\
\hline & & Executive & 15 & 3 & 91.67 & 2 & $\mathbf{1 . 8 3}$ & Agreeing & \\
\hline & & Total sample & 27 & 5 & 92.19 & 5 & 1.84 & Agreeing & 15.13 \\
\hline 13 & Assisting the incubated projects to: & & & & & & & & \\
\hline 13/1 & $\begin{array}{l}\text { Developing and evaluating and } \\
\text { identifying training needs of their }\end{array}$ & $\begin{array}{l}\text { Supreme and } \\
\text { middle }\end{array}$ & 13 & 1 & 96.43 & 2 & 1.93 & Agreeing & 0.65 \\
\hline & employees & Executive & 15 & 3 & 91.67 & 2 & 1.83 & Agreeing & \\
\hline & & Total sample & 28 & 4 & 93.75 & 1 & 1.88 & Agreeing & 18 \\
\hline $13 / 2$ & $\begin{array}{l}\text { Improving and developing their } \\
\text { productive operations and }\end{array}$ & $\begin{array}{l}\text { Supreme and } \\
\text { middle }\end{array}$ & 12 & 2 & 92.86 & 6 & 1.86 & Agreeing & 0.84 \\
\hline & evaluating their organizational & Executive & 13 & 5 & 86.11 & 11 & 1.72 & Agreeing & \\
\hline & performance completely & Total sample & 25 & 7 & 89.06 & 9 & 1.78 & Agreeing & 10.13 \\
\hline 14 & Designing an informational system & & & & & & & & \\
\hline $14 / 1$ & Employees & $\begin{array}{l}\text { Supreme and } \\
\text { middle }\end{array}$ & 13 & 1 & 96.43 & 2 & 1.93 & Agreeing & 1.36 \\
\hline & & Executive & 14 & 4 & 88.89 & 5 & 1.78 & Agreeing & \\
\hline & & Total sample & 27 & 5 & 92.19 & 5 & 1.84 & Agreeing & 15.13 \\
\hline $14 / 2$ & Suppliers & $\begin{array}{c}\text { Supreme and } \\
\text { middle }\end{array}$ & 9 & 5 & 82.14 & 16 & 1.64 & Agreeing & 1.24 \\
\hline & & Executive & 8 & 10 & 72.22 & 17 & 1.44 & Agreeing & \\
\hline & & Total sample & 17 & 15 & 76.56 & 17 & 1.53 & Agreeing & 0.13 \\
\hline $14 / 3$ & Beneficiaries & $\begin{array}{l}\text { Supreme and } \\
\text { middle }\end{array}$ & 10 & 4 & 85.71 & 12 & 1.71 & Agreeing & 0.85 \\
\hline & & Executive & 10 & 8 & 77.78 & 15 & 1.56 & Agreeing & \\
\hline & & Total sample & 20 & 12 & 81.25 & 14 & 1.63 & Agreeing & 2 \\
\hline $14 / 4$ & Competitive projects & $\begin{array}{c}\text { Supreme and } \\
\text { middle }\end{array}$ & 10 & 4 & 85.71 & 12 & 1.71 & Agreeing & 1.5 \\
\hline & & Executive & 9 & 9 & 75 & 16 & 1.5 & Agreeing & \\
\hline & & Total sample & 19 & 13 & 79.69 & 16 & 1.59 & Agreeing & 1.13 \\
\hline 15 & $\begin{array}{c}\text { Following up and evaluating the } \\
\text { incubated projects }\end{array}$ & & & & & & & & \\
\hline $15 / 1$ & Regularly & $\begin{array}{l}\text { Supreme and } \\
\text { middle }\end{array}$ & 13 & 1 & 96.43 & 2 & 1.93 & Agreeing & 1.36 \\
\hline & & Executive & 14 & 4 & 88.89 & 5 & 1.78 & Agreeing & \\
\hline & & Total sample & 27 & 5 & 92.19 & 5 & 1.84 & Agreeing & 15.13 \\
\hline
\end{tabular}




\begin{tabular}{|c|c|c|c|c|c|c|c|c|c|}
\hline \multirow[t]{3}{*}{$15 / 2$} & \multirow[t]{3}{*}{ After incubation } & $\begin{array}{l}\text { Supreme and } \\
\text { middle }\end{array}$ & 9 & 5 & 82.14 & 16 & 1.64 & Agreeing & \multirow[t]{2}{*}{0.03} \\
\hline & & Executive & 11 & 7 & 80.56 & 14 & 1.61 & Agreeing & \\
\hline & & Total sample & 20 & 12 & 81.25 & 14 & 1.63 & Agreeing & 2 \\
\hline \multirow[t]{3}{*}{16} & \multirow{3}{*}{$\begin{array}{c}\text { Taking the incubated project's } \\
\text { corrective procedures as per } \\
\text { evaluation results }\end{array}$} & $\begin{array}{c}\text { Supreme and } \\
\text { middle }\end{array}$ & 11 & 3 & 89.29 & 10 & 1.79 & Agreeing & \multirow[t]{2}{*}{$\mathbf{0}$} \\
\hline & & Executive & 14 & 4 & 88.89 & 5 & 1.78 & Agreeing & \\
\hline & & Total sample & 25 & 7 & 89.06 & 9 & 1.78 & Agreeing & 10.13 \\
\hline \multirow[t]{3}{*}{17} & \multirow{3}{*}{$\begin{array}{l}\text { Identifying strong points of the } \\
\text { incubated projects to support, } \\
\text { and weak points to overcome }\end{array}$} & $\begin{array}{l}\text { Supreme and } \\
\text { middle }\end{array}$ & 12 & 2 & 92.86 & 6 & 1.86 & Agreeing & \multirow[t]{2}{*}{0.33} \\
\hline & & Executive & 14 & 4 & 88.89 & 5 & 1.78 & Agreeing & \\
\hline & & Total sample & 26 & 6 & 90.63 & 8 & 1.81 & Agreeing & 12.5 \\
\hline
\end{tabular}

Value of $\mathrm{Ca}^{2}(1,0.05)=3.841, \mathrm{Ca}^{2}(2,0.05)=5.991$

Weights outweighed arithmetic mean: disagreeing (1: 1.5), agreeing (2: 1.6)

From table number (6), there are no statistical significant difference between the responses of the research samples groups, as the calculated $\mathrm{Ca}^{2}$ was less than its tabular value at level $(0.05)$ and ranged between $(0: 3.56)$, with outweighed percentage between $(76.56: 93.56)$ in the agreement direction.

According to the total research sample opinions, statements number $(8,9,11$, and 13/1) toped their opinions with an outweighed percentage (93.75) indicating establishing a high qualified administrative and technical team to provide advice and guide, compiling strategies of the incubated entrepreneurial project.

Results of study of Khalid Salah (2016) (14), Mona Radwan Elnakhala (2012) (19) indicate that business incubators avail the suitable environment of establishing and executing entrepreneurial projects, as statements number (14/2/14/4,15/2) took the last place with an outweighed percentage $(76.56,81.25)$ upon that designing an information system, following up and evaluating the incubated project after incubation. Results of study of Hayat Bakirat (2017) (9), Rima Mohamed (2005) (22) indicate that business incubators contributes to preparing programs of evaluating and following up the incubated project.

Table (7) Results of Repetitions, Percentages and $\left(\mathrm{Ca}^{2}\right)$ on the First Factor: The Fact of Business Incubators, Ministry of Youth and Sports - the Second Factor: Business Incubators Mechanism (B- Legal Aspects) 
$($ Supreme and Middle Department $=14)($ Executive Department $=18)($ Total

Sample $=32$ )

\begin{tabular}{|c|c|c|c|c|c|c|c|c|c|}
\hline $\mathbf{S}$ & Statement Content & Departments & Agreeing & Disagreeing & $\begin{array}{l}\text { Outweighed } \\
\text { Percentage }\end{array}$ & Order & Average & $\begin{array}{l}\text { Common } \\
\text { Attitude }\end{array}$ & Ca 2 \\
\hline 18 & \multicolumn{9}{|c|}{ Business incubators provide legal support to incubated projects via availing the following: } \\
\hline \multirow[t]{3}{*}{ 18/1 } & \multirow{3}{*}{$\begin{array}{l}\text { Legal services for establishing } \\
\text { and managing incubated } \\
\text { projects }\end{array}$} & $\begin{array}{l}\text { Supreme and } \\
\text { middle }\end{array}$ & 12 & 2 & 92.86 & 1 & 1.86 & Agreeing & \multirow[t]{2}{*}{$\mathbf{0 . 0 3}$} \\
\hline & & Executive & 15 & 3 & 91.67 & 1 & 1.83 & Agreeing & \\
\hline & & Total sample & 27 & 5 & 92.19 & 1 & 1.84 & Agreeing & 15.13 \\
\hline \multirow[t]{3}{*}{$18 / 2$} & \multirow{3}{*}{$\begin{array}{c}\text { Information about tax laws to } \\
\text { which the incubated projects } \\
\text { are subject }\end{array}$} & $\begin{array}{c}\text { Supreme and } \\
\text { middle }\end{array}$ & 9 & 5 & 82.14 & 2 & 1.64 & Agreeing & \multirow[t]{2}{*}{0.02} \\
\hline & & Executive & 12 & 6 & 83.33 & 2 & 1.67 & Agreeing & \\
\hline & & Total sample & 21 & 11 & 82.81 & 2 & 1.66 & Agreeing & 3.13 \\
\hline \multirow[t]{3}{*}{$18 / 3$} & \multirow[t]{3}{*}{$\begin{array}{c}\text { Programs of awareness of legal } \\
\text { updates }\end{array}$} & $\begin{array}{l}\text { Supreme and } \\
\text { middle }\end{array}$ & 8 & 6 & 78.57 & 3 & 1.57 & Agreeing & \multirow[t]{2}{*}{0.3} \\
\hline & & Executive & 12 & 6 & 83.33 & 2 & 1.67 & Agreeing & \\
\hline & & Total sample & 20 & 12 & 81.25 & 3 & 1.63 & Agreeing & 2 \\
\hline \multirow[t]{3}{*}{$18 / 4$} & \multirow[t]{3}{*}{$\begin{array}{l}\text { Intellectual property rights } \\
\text { protection mechanisms }\end{array}$} & $\begin{array}{c}\text { Supreme and } \\
\text { middle }\end{array}$ & 7 & 7 & 75 & 4 & 1.5 & Agreeing & \multirow[t]{2}{*}{0.1} \\
\hline & & Executive & 10 & 8 & 77.78 & 4 & 1.56 & Agreeing & \\
\hline & & Total sample & 17 & 15 & 76.56 & 4 & 1.53 & Agreeing & 0.13 \\
\hline
\end{tabular}

Value of $\mathrm{Ca}^{2}(1,0.05)=3.841, \mathrm{Ca}^{2}(2,0.05)=5.991$

Arithmetic mean outweighed by weight: disagreeing (1: 1.5), agreeing (2: 1.6)

From table number(7), there are no statistical significant difference between responses

of the research sample groups, as the calculated $\left(\mathrm{Ca}^{2}\right)$ is less than its tabular value at level (0.05) and ranged between (0.02:0.30), with an outweighed percentage between (76.56: 92.19) in the agreement direction.

According to the total research sample's opinion, the statements order were as follows $(18 / 1,18 / 2,18 / 3,18 / 4)$ to indicate that business incubators provide legal support to the incubated projects, information about tax laws to which the incubated projects are subject and legal updates awareness programs.

Results of study of Malden Elkayal (2017) (17), Rond Khalid (2015) (23) prove that business incubators play an important role in informing about legal requirements related to establishing the project as well as tax legislations related to the incubated project.

Table (8) Results of Repetitions, Percentages and $\left(\mathrm{Ca}^{2}\right)$ on the First Factor: The Fact of Business Incubators at Ministry of Youth and Sports - The Second

Dimension: Business Incubators Mechanisms (C - Financial Aspects) $($ Supreme and Middle Department $=14)($ Executive Department= 18 $)($ Total $=32)$ 


\begin{tabular}{|c|c|c|c|c|c|c|c|c|c|}
\hline $\mathbf{S}$ & Statement Content & Departments & Agreeing & Disagreeing & $\begin{array}{l}\text { Outweighed } \\
\text { Percentage }\end{array}$ & Order & Average & $\begin{array}{l}\text { Common } \\
\text { Attitude }\end{array}$ & Ca 2 \\
\hline 19 & \multicolumn{9}{|c|}{ Verifying the feasibility of incubating the project and evaluating its success possibility through: } \\
\hline \multirow[t]{3}{*}{$19 / 1$} & \multirow[t]{3}{*}{$\begin{array}{l}\text { Carrying out the project's } \\
\text { feasibility study }\end{array}$} & $\begin{array}{l}\text { Supreme and } \\
\text { middle }\end{array}$ & 13 & 1 & 96.43 & 1 & 1.93 & Agreeing & \multirow[t]{2}{*}{2.2} \\
\hline & & Executive & 13 & 5 & 86.11 & 2 & 1.72 & Agreeing & \\
\hline & & Total sample & 26 & 6 & 90.63 & 1 & 1.81 & Agreeing & 12.5 \\
\hline \multirow[t]{3}{*}{$19 / 2$} & \multirow[t]{3}{*}{$\begin{array}{l}\text { Accounting and legal consultation } \\
\text { of establishing the new project }\end{array}$} & $\begin{array}{l}\text { Supreme and } \\
\text { middle }\end{array}$ & 11 & 3 & 89.29 & 3 & 1.79 & Agreeing & \multirow[t]{2}{*}{0.55} \\
\hline & & Executive & 12 & 6 & 83.33 & 4 & 1.67 & Agreeing & \\
\hline & & Total sample & 23 & 9 & 85.94 & 4 & 1.72 & Agreeing & 6.13 \\
\hline \multirow[t]{3}{*}{20} & \multirow{3}{*}{$\begin{array}{l}\text { Playing the role of mediator } \\
\text { between businessmen and } \\
\text { entrepreneurial ideas compilers }\end{array}$} & $\begin{array}{c}\text { Supreme and } \\
\text { middle }\end{array}$ & 10 & 4 & 85.71 & 5 & 1.71 & Agreeing & \multirow[t]{2}{*}{0.85} \\
\hline & & Executive & 10 & 8 & 77.78 & 7 & 1.56 & Agreeing & \\
\hline & & Total sample & 20 & 12 & 81.25 & 7 & 1.63 & Agreeing & 2 \\
\hline \multirow[t]{3}{*}{21} & \multirow{3}{*}{$\begin{array}{l}\text { Effective coordination with } \\
\text { governmental authorities and } \\
\text { ministry of planning to obtain } \\
\text { financial support for } \\
\text { entrepreneurial projects. }\end{array}$} & $\begin{array}{l}\text { Supreme and } \\
\text { middle }\end{array}$ & 12 & 2 & 92.86 & 2 & 1.86 & Agreeing & \multirow[t]{2}{*}{0.33} \\
\hline & & Executive & 14 & 4 & 88.89 & 1 & 1.78 & Agreeing & \\
\hline & & Total sample & 26 & 6 & 90.63 & 1 & 1.81 & Agreeing & 12.5 \\
\hline \multirow[t]{3}{*}{22} & \multirow{3}{*}{$\begin{array}{l}\text { Concluding agreements with } \\
\text { international authorities to avail } \\
\text { foreign finance }\end{array}$} & $\begin{array}{l}\text { Supreme and } \\
\text { middle }\end{array}$ & 8 & 6 & 78.57 & 8 & 1.57 & Agreeing & \multirow[t]{2}{*}{0.16} \\
\hline & & Executive & 9 & 9 & 75 & 8 & 1.5 & Agreeing & \\
\hline & & Total sample & 17 & 15 & 76.56 & 8 & 1.53 & Agreeing & 0.13 \\
\hline \multirow[t]{3}{*}{23} & \multirow{3}{*}{$\begin{array}{l}\text { Providing advice and experience } \\
\text { to reduce expenses and operating } \\
\text { costs via experience center and } \\
\text { knowledge sources }\end{array}$} & $\begin{array}{c}\text { Supreme and } \\
\text { middle }\end{array}$ & 9 & 5 & 82.14 & & 1.64 & Agreeing & \multirow[t]{2}{*}{0.02} \\
\hline & & Executive & 12 & 6 & 83.33 & 4 & 1.67 & Agreeing & \\
\hline & & Total sample & 21 & 11 & 82.81 & 5 & 1.66 & Agreeing & 3.13 \\
\hline \multirow[t]{3}{*}{24} & \multirow{3}{*}{$\begin{array}{c}\text { Making market studies to identify } \\
\text { demand level and beneficiaries' } \\
\text { needs }\end{array}$} & $\begin{array}{c}\text { Supreme and } \\
\text { middle }\end{array}$ & 10 & 4 & 85.71 & 5 & 1.71 & Agreeing & \multirow[t]{2}{*}{0.37} \\
\hline & & Executive & 11 & 7 & 80.56 & 6 & 1.61 & Agreeing & \\
\hline & & Total sample & 21 & 11 & 82.81 & 5 & 1.66 & Agreeing & 3.13 \\
\hline \multirow[t]{3}{*}{25} & \multirow{3}{*}{$\begin{array}{l}\text { Preparing marketing programs to } \\
\text { promote the incubated projects' } \\
\text { products and service }\end{array}$} & $\begin{array}{c}\text { Supreme and } \\
\text { middle }\end{array}$ & 11 & 3 & 89.29 & 3 & 1.79 & Agreeing & \multirow[t]{2}{*}{0.17} \\
\hline & & Executive & 13 & 5 & 86.11 & 2 & 1.72 & Agreeing & \\
\hline & & Total sample & 24 & 8 & 87.5 & 3 & 1.75 & Agreeing & 8 \\
\hline
\end{tabular}

Value of $\mathrm{Ca}^{2}(1,0.05)=3.841, \mathrm{Ca}^{2}(2,0.05)=5.991$

Arithmetic mean outweighed by weight: disagreeing (1: 1.5), agreeing (2: 1.6)

From table number (8) there are no statistical significant differences between responses of the research sample's group about all statement of the second dimension ( $\mathrm{C}$ - financial aspects ) as the calculated ( $\mathrm{Ca}^{2}$ ) was less than its tabular value at level $(0.05)$ and ranged between $(0.02: 2.20)$, with an outweighed percentage between $(76.56$ : 90.63) in the agreement direction.

According to the whole research sample's opinion, statements number $(19 / 1,21,25)$ toped their opinions with an outweighed percentage between $(87.5: 90.63)$ to verify the feasibility of incubating the project and evaluate its success possibility via carrying out the project's feasibility study.

Results of study of Mona Radwan Elnakhala (2012) (19) indicates that there should be more financial and market services for small size incubated projects, dealing with the problem of financing incubators by allocating sums needed for their establishment and permanency. 
As statements number $(20,22)$ took the last place with an outweighed percentage $(81.25,76.56)$ respectively to indicate that incubators play the role of mediator between businessmen and entrepreneurial ideas compilers.

Results of study of Magda Soliman Artima (2012) (15) indicates carrying out an economic feasibility study for the incubated project's activity and directing financial support in conformity with the project's nature.

Table (9) Results of Repetitions, Percentages and $\left(\mathrm{Ca}^{2}\right)$ on the First Factor: The Fact

Business Incubators at Ministry of Youth and Sports - The Second Factor: Business

Incubators Mechanisms (D - Financial Aspects)

$($ Supreme and Middle Department $=14)($ Executive Department $=18)($ Total $=32)$

\begin{tabular}{|c|c|c|c|c|c|c|c|c|c|}
\hline $\mathbf{S}$ & Statement Content & Departments & Agreeing & Disagreeing & $\begin{array}{l}\text { Outweighed } \\
\text { Percentage }\end{array}$ & Order & Average & $\begin{array}{l}\text { Common } \\
\text { Attitude }\end{array}$ & Ca 2 \\
\hline \multirow[t]{3}{*}{26} & \multirow{3}{*}{$\begin{array}{l}\text { The incubator allocates the suitable } \\
\text { surface area in conformity with the } \\
\text { incubated project's activity. }\end{array}$} & $\begin{array}{l}\text { Supreme and } \\
\text { middle }\end{array}$ & 12 & 2 & 92.86 & 1 & 1.86 & Agreeing & \multirow[t]{2}{*}{$\mathbf{0 . 0 3}$} \\
\hline & & Executive & 15 & 3 & 91.67 & $\mathbf{1}$ & $\mathbf{1 . 8 3}$ & Agreeing & \\
\hline & & Total sample & 27 & 5 & 92.19 & $\mathbf{1}$ & 1.84 & Agreeing & 15.13 \\
\hline 27 & \multicolumn{9}{|c|}{ The incubator avails all facilities and services needed by the project such as: } \\
\hline \multirow[t]{3}{*}{$27 / 1$} & \multirow{3}{*}{$\begin{array}{l}\text { Modern means of communication" } \\
\text { phone, fax and internet" }\end{array}$} & $\begin{array}{c}\text { Supreme and } \\
\text { middle }\end{array}$ & 11 & 3 & 89.29 & 2 & 1.79 & Agreeing & \multirow[t]{2}{*}{0.55} \\
\hline & & Executive & 12 & 6 & 83.33 & 4 & 1.67 & Agreeing & \\
\hline & & Total sample & 23 & 9 & 85.94 & 4 & 1.72 & Agreeing & 6.13 \\
\hline \multirow[t]{3}{*}{$27 / 2$} & \multirow[t]{3}{*}{ Appliances suitable for the project } & $\begin{array}{c}\text { Supreme and } \\
\text { middle }\end{array}$ & 11 & 3 & 89.29 & 2 & 1.79 & Agreeing & \multirow[t]{2}{*}{$\overline{\mathbf{0}}$} \\
\hline & & Executive & 14 & 4 & 88.89 & 2 & 1.78 & Agreeing & \\
\hline & & Total sample & 25 & 7 & 89.06 & 2 & 1.78 & Agreeing & 10.13 \\
\hline \multirow[t]{3}{*}{$27 / 3$} & \multirow[t]{3}{*}{ Meeting and training hall } & $\begin{array}{c}\text { Supreme and } \\
\text { middle }\end{array}$ & 9 & 5 & 82.14 & $\overline{6}$ & 1.64 & $\overline{\text { Agreeing }}$ & \multirow[t]{2}{*}{0.25} \\
\hline & & Executive & 10 & 8 & 77.78 & 6 & 1.56 & Agreeing & \\
\hline & & Total sample & 19 & 13 & 79.69 & 6 & 1.59 & Agreeing & 1.13 \\
\hline \multirow[t]{3}{*}{$27 / 4$} & \multirow[t]{3}{*}{ High quality infrastructure } & $\begin{array}{c}\text { Supreme and } \\
\text { middle }\end{array}$ & 11 & 3 & 89.29 & 2 & 1.79 & Agreeing & \multirow[t]{2}{*}{0.17} \\
\hline & & Executive & 13 & 5 & 86.11 & 3 & 1.72 & Agreeing & \\
\hline & & Total sample & 24 & 8 & 87.5 & 3 & 1.75 & Agreeing & 8 \\
\hline \multirow[t]{3}{*}{28} & \multirow{3}{*}{$\begin{array}{l}\text { Regular follow up and maintenance } \\
\text { of the project's infrastructure. }\end{array}$} & $\begin{array}{c}\text { Supreme and } \\
\text { middle }\end{array}$ & 10 & 4 & 85.71 & 5 & 1.71 & Agreeing & \multirow[t]{2}{*}{0.37} \\
\hline & & Executive & 11 & 7 & 80.56 & 5 & 1.61 & Agreeing & \\
\hline & & Total sample & 21 & 11 & 82.81 & 5 & 1.66 & Agreeing & 3.13 \\
\hline
\end{tabular}

Value of $\mathrm{Ca}^{2}(1,0.05)=3.841, \mathrm{Ca}^{2}(2,0.05)=5.991$

Arithmetic mean outweighed by weight: disagreeing (1: 1.5), agreeing (2: 1.6)

From table number (9), it is clear that there are no statistical significant differences between responses of the research sample's groups as the value of the calculated $\left(\mathrm{Ca}^{2}\right)$ was less than its tabular value at level $(0.05)$ and ranged between $(0.00: 0.55)$, with an outweighed percentage between $(79.69: 92.19)$ in the agreement direction.

According to the whole research sample, it was found that statements number $(26,27 / 2$ , 27/4) toped the research sample's opinion with an outweighed percentage between 
(87.5 : 92.19) indicating that the incubator allocates a suitable surface area in conformity with the incubated project's activity, the incubator avails all facilities and services needed by the project.

Omran Mohamed Elfawaz (2014) (20), in his study recommends the importance of motivating entrepreneurs to work in a technical environment provided with the best techniques and equipments to enable them to convert their ideas to products and services serving community and national economy.

As statements number $(28,27 / 3)$ took the last place indicating regular follow up and maintenance of the project infrastructure, incubators avail all facilities and services needed by the project.

Results of study of Malden Mosleh Elkayal (2017) (17), proves that the incubating organization avails a suitable infrastructure and all services needed by the incubated project.

Table (10) Results of Repetitions, Percentages and $\left(\mathrm{Ca}^{2}\right)$ on the Second Factor: The Role of Ministry of Youth and Sports in Enhancing Culture of Entrepreneurship. $($ Supreme\& Middle Department = 14 $)($ Executive Department= 18) $($ Total $=32)$ 


\begin{tabular}{|c|c|c|c|c|c|c|c|c|c|}
\hline $\mathbf{S}$ & Statement Content & Departments & Agreeing & $\begin{array}{l}\text { Disagreei } \\
\text { ng }\end{array}$ & $\begin{array}{l}\text { Outweighed } \\
\text { Percentage }\end{array}$ & Order & Average & $\begin{array}{l}\text { Common } \\
\text { Attitude }\end{array}$ & Ca 2 \\
\hline 29 & Ministry of youth and sport & directions towal & establishin & business inc & bators to adop & entrepre & urial proje & S via: & \\
\hline \multirow[t]{3}{*}{$29 / 1$} & \multirow{3}{*}{$\begin{array}{l}\text { Ministry of youth and sports keenness to } \\
\text { clarify the role of business incubators for } \\
\text { entrepreneurial ideas compilers }\end{array}$} & $\begin{array}{c}\text { Supreme and } \\
\text { middle }\end{array}$ & 12 & 2 & 92.86 & 2 & 1.86 & Agreeing & \multirow[t]{2}{*}{0.07} \\
\hline & & Executive & 16 & 2 & 94.44 & 1 & 1.89 & Agreeing & \\
\hline & & Total sample & 28 & 4 & 93.75 & 2 & 1.88 & Agreeing & 18 \\
\hline \multirow[t]{3}{*}{$29 / 2$} & \multirow{3}{*}{$\begin{array}{l}\text { Adopting and supporting } \\
\text { entrepreneurial culture }\end{array}$} & $\begin{array}{l}\text { Supreme and } \\
\text { middle }\end{array}$ & 14 & $\mathbf{0}$ & 100 & 1 & 2 & Agreeing & \multirow[t]{2}{*}{2.57} \\
\hline & & Executive & 15 & 3 & 91.67 & 3 & $\mathbf{1 . 8 3}$ & Agreeing & \\
\hline & & Total sample & 29 & 3 & 95.31 & 1 & 1.91 & Agreeing & 21.13 \\
\hline \multirow[t]{3}{*}{$29 / 3$} & \multirow{3}{*}{$\begin{array}{l}\text { Developing an entrepreneurial culture } \\
\text { via courses, seminars and meetings }\end{array}$} & $\begin{array}{l}\text { Supreme and } \\
\text { middle }\end{array}$ & 11 & 3 & 89.29 & 3 & 1.79 & Agreeing & \multirow[t]{2}{*}{0.55} \\
\hline & & Executive & 12 & 6 & 83.33 & 7 & 1.67 & Agreeing & \\
\hline & & Total sample & 23 & 9 & 85.94 & 4 & 1.72 & Agreeing & 6.13 \\
\hline \multirow[t]{3}{*}{$29 / 4$} & \multirow{3}{*}{$\begin{array}{l}\text { Cooperation with the private sector to } \\
\text { support entrepreneurship at sports } \\
\text { sector }\end{array}$} & $\begin{array}{c}\text { Supreme and } \\
\text { middle }\end{array}$ & 8 & 6 & 78.57 & 9 & 1.57 & Agreeing & \multirow[t]{2}{*}{0.05} \\
\hline & & Executive & 11 & 7 & 80.56 & 9 & 1.61 & Agreeing & \\
\hline & & Total sample & 19 & 13 & 79.69 & 10 & 1.59 & Agreeing & 1.13 \\
\hline \multirow[t]{3}{*}{$29 / 5$} & \multirow{3}{*}{$\begin{array}{l}\text { Clarifying conditions and requirements } \\
\text { admittance for entrepreneurial projects } \\
\text { at business incubators }\end{array}$} & $\begin{array}{c}\text { Supreme and } \\
\text { middle }\end{array}$ & 10 & 4 & 85.71 & 4 & 1.71 & Agreeing & \multirow[t]{2}{*}{0.17} \\
\hline & & Executive & 14 & 4 & 88.89 & 4 & 1.78 & Agreeing & \\
\hline & & Total sample & 24 & 8 & 87.5 & 3 & 1.75 & Agreeing & 8 \\
\hline \multirow[t]{3}{*}{$29 / 6$} & \multirow{3}{*}{$\begin{array}{l}\text { Evaluating entrepreneurial projects to } \\
\text { assist in incubators admittance }\end{array}$} & $\begin{array}{c}\text { Supreme and } \\
\text { middle }\end{array}$ & 9 & 5 & 82.14 & 5 & 1.64 & Agreeing & \multirow[t]{2}{*}{0.02} \\
\hline & & Executive & 12 & 6 & 83.33 & 7 & 1.67 & Agreeing & \\
\hline & & Total sample & 21 & 11 & 82.81 & 7 & 1.66 & Agreeing & 3.13 \\
\hline 30 & Ministry of youth and spor & faces some rest & tions relate & develop & culture of ent & preneur & ip represen & in & \\
\hline \multirow[t]{3}{*}{$30 / 1$} & \multirow{3}{*}{$\begin{array}{c}\text { The ministry's late concern about } \\
\text { entrepreneurship compared to other } \\
\text { ministries and authorities }\end{array}$} & $\begin{array}{c}\text { Supreme and } \\
\text { middle }\end{array}$ & 4 & 10 & 64.29 & 12 & 1.29 & Agreeing & \multirow[t]{2}{*}{12.22} \\
\hline & & Executive & 16 & 2 & 94.44 & 1 & 1.89 & Agreeing & \\
\hline & & Total sample & 20 & 12 & 81.25 & 9 & 1.63 & Agreeing & 2 \\
\hline \multirow[t]{3}{*}{$30 / 2$} & \multirow{3}{*}{$\begin{array}{l}\text { Some persons have inherited cultures of } \\
\text { cleaving to governmental jobs }\end{array}$} & $\begin{array}{c}\text { Supreme and } \\
\text { middle }\end{array}$ & 9 & 5 & 82.14 & $\overline{5}$ & 1.64 & Agreeing & \multirow[t]{2}{*}{0.03} \\
\hline & & Executive & 11 & 7 & 80.56 & 9 & 1.61 & Agreeing & \\
\hline & & Total sample & 20 & 12 & $\mathbf{8 1 . 2 5}$ & 9 & 1.63 & Agreeing & 2 \\
\hline \multirow[t]{3}{*}{$30 / 3$} & $\begin{array}{l}\text { Lack of technical coordinators of } \\
\text { discovering entrepreneurial ideas }\end{array}$ & $\begin{array}{c}\text { Supreme and } \\
\text { middle }\end{array}$ & 8 & 6 & 78.57 & 9 & 1.57 & Agreeing & 1.56 \\
\hline & a & Executive & 14 & 4 & 88.89 & 44 & 1.78 & Agreeing & \\
\hline & & Total sample & 22 & 10 & 84.38 & 5 & 1.69 & Agreeing & 4.5 \\
\hline $30 / 4$ & Lack of entrepreneurial projects & $\begin{array}{c}\text { Supreme and } \\
\text { middle }\end{array}$ & 9 & 5 & 82.14 & 5 & 1.64 & Agreeing & 0.23 \\
\hline & comples com & Executive & 13 & 5 & 86.11 & 6 & 1.72 & Agreeing & \\
\hline & youtn and sports support & Total sample & 22 & 10 & 84.38 & 5 & 1.69 & Agreeing & 4.5 \\
\hline $30 / 5$ & $\begin{array}{c}\text { Lack of perfect data base and statistics } \\
\text { about market requirements }\end{array}$ & $\begin{array}{c}\text { Supreme and } \\
\text { middle }\end{array}$ & 9 & 5 & 82.14 & 5 & 1.64 & Agreeing & 0.65 \\
\hline & & Executive & 9 & 9 & 75 & 11 & 1.5 & Agreeing & \\
\hline & & Total sample & 18 & 14 & 78.13 & 11 & 1.56 & Agreeing & 0.5 \\
\hline $30 / 6$ & Non updating business incubators with & $\begin{array}{c}\text { Supreme and } \\
\text { middle }\end{array}$ & 7 & 7 & 75 & 11 & 1.5 & Agreeing & 0.4 \\
\hline & $\mathbf{S}$ & Executive & 7 & 11 & 69.44 & 12 & 1.39 & Agreeing & \\
\hline & & Total sample & 14 & 18 & 71.88 & 12 & 1.44 & Agreeing & 0.5 \\
\hline
\end{tabular}

Value of $\mathrm{Ca}^{2}(1,0.05)=3.841, \mathrm{Ca}^{2}(2,0.05)=5.991$

Arithmetic mean outweighed by weight: disagreeing (1: 1.5), agreeing (2: 1.6)

From table number (10), there are no statistical significant difference between

responses of the research sample groups about the factor's statements as calculated 
value of $\left(\mathrm{Ca}^{2}\right)$ was less than its tabular value at level (0.05) and ranged between (0.05: 1.56), with an outweighed percentage between (71.13: 93.75), except for statements number (30/1) as value of $\left(\mathrm{Ca}^{2)}\right.$ reached (12.22).

According to whole research sample's opinion, statements numbers $(29 / 2,29 / 1,29 / 5$, 29/3) toped their opinions with an outweighed percentage between (85.94:93.75) indicating ministry of youth and sports direction towards establishing business incubators to adopt entrepreneurial projects via adopting and supporting entrepreneurship culture, clarifying conditions and requirements of accepting entrepreneurial projects at business incubators.

Results of Bassem Eldilimy (2019) (7), Abdelmawgoud Abdalla, Kossay Sary (2016) (1), Anwar Elazzam (2009) (6) agreed upon the importance of developing entrepreneurship culture through culturing seminars and designing training programs to develop skills of entrepreneurial projects compilers in conformity with the project's objective.

While statements numbers $(30 / 5,30 / 6)$ took the last place with an outweighed percentage $(78.13,71.88)$ respectively indicating that ministry of youth and sports faces some restrictions regarding developing entrepreneurship culture, not updating the incubator's web site with all new activities and norms.

Results of study of Hayat Bakirat (2017) (9) clarifies that business incubators contribute to finding the aimed markets and availing information about consumers' taste.

Table (11) Results of Repetitions, Percentage and $\left(\mathrm{Ca}^{2}\right)$ on the Third Factor: The Role of Business Incubators and Entrepreneurial Projects in Supporting Economy in the Light of Egypt's Vision 2030.

$($ Supreme and Middle Department $=14)($ Executive Department $=18)($ Total $=32)$

\begin{tabular}{|c|c|c|c|c|c|c|c|c|c|}
\hline $\mathbf{S}$ & Statement Content & Departments & Agreeing & Disagreeing & $\begin{array}{l}\text { Outweighed } \\
\text { Percentage }\end{array}$ & Order & Average & $\begin{array}{c}\text { Common } \\
\text { Attitude }\end{array}$ & Ca 2 \\
\hline 31 & Anti unemployment via: & & & & & & & & \\
\hline
\end{tabular}




\begin{tabular}{|c|c|c|c|c|c|c|c|c|c|}
\hline \multirow[t]{3}{*}{$31 / 1$} & \multirow{3}{*}{$\begin{array}{c}\text { Enabling youth to carry out small } \\
\text { projects }\end{array}$} & $\begin{array}{c}\text { Supreme and } \\
\text { middle }\end{array}$ & 13 & 1 & 96.43 & 4 & 1.93 & Agreeing & \multirow[t]{2}{*}{2.2} \\
\hline & & Executive & 13 & 5 & 86.11 & 7 & 1.72 & Agreeing & \\
\hline & & Total sample & 26 & 6 & 90.63 & 5 & 1.81 & Agreeing & 12.5 \\
\hline \multirow[t]{3}{*}{$31 / 2$} & \multirow{3}{*}{$\begin{array}{c}\text { Encouraging them to join labor } \\
\text { market }\end{array}$} & $\begin{array}{c}\text { Supreme and } \\
\text { middle }\end{array}$ & 12 & 2 & 82.86 & 6 & 1.86 & Agreeing & \multirow[t]{2}{*}{0.33} \\
\hline & & Executive & 14 & 4 & 88.89 & 5 & 1.78 & Agreeing & \\
\hline & & Total sample & 26 & 6 & 90.63 & 5 & 1.81 & Agreeing & 12.5 \\
\hline \multirow[t]{3}{*}{$31 / 3$} & \multirow{3}{*}{$\begin{array}{c}\text { Creating new jobs and encouraging } \\
\text { stagnant sectors }\end{array}$} & $\begin{array}{l}\text { Supreme and } \\
\text { middle }\end{array}$ & 10 & 4 & 85.71 & 9 & 1.71 & Agreeing & \multirow[t]{2}{*}{1.58} \\
\hline & & Executive & 16 & 2 & 94.44 & 2 & 1.89 & Agreeing & \\
\hline & & Total sample & 26 & 6 & 90.63 & 5 & 1.81 & Agreeing & 12.5 \\
\hline \multirow[t]{3}{*}{32} & \multirow{3}{*}{$\begin{array}{l}\text { Carrying out new entrepreneurial } \\
\text { projects used in executing } \\
\text { permanent development } \\
\text { mechanisms. }\end{array}$} & $\begin{array}{l}\text { Supreme and } \\
\text { middle }\end{array}$ & 14 & $\mathbf{0}$ & 100 & 1 & 2 & Agreeing & \multirow[t]{2}{*}{0.8} \\
\hline & & Executive & 17 & 1 & 97.22 & 1 & 1.91 & Agreeing & \\
\hline & & Total sample & 31 & 1 & 98.44 & 1 & 1.97 & Agreeing & 28.13 \\
\hline 33 & \multicolumn{9}{|l|}{ Entrepreneurial projects' contribution to } \\
\hline \multirow[t]{3}{*}{$33 / 1$} & \multirow[t]{3}{*}{ Increasing individual's income } & $\begin{array}{l}\text { Supreme and } \\
\text { middle }\end{array}$ & 13 & 1 & 96.43 & & 1.93 & Agreeing & \multirow[t]{2}{*}{1.65} \\
\hline & & Executive & 15 & 3 & 91.67 & & 1.83 & Agreeing & \\
\hline & & Total sample & 28 & 4 & 93.75 & 3 & 1.88 & Agreeing & 18 \\
\hline \multirow[t]{3}{*}{$33 / 2$} & \multirow{3}{*}{$\begin{array}{c}\text { Increasing the total state national } \\
\text { product }\end{array}$} & $\begin{array}{l}\text { Supreme and } \\
\text { middle }\end{array}$ & 14 & $\mathbf{0}$ & 100 & 1 & 2 & Agreeing & \multirow[t]{2}{*}{1.66} \\
\hline & & Executive & 16 & 2 & 94.44 & 2 & 1.89 & Agreeing & \\
\hline & & Total sample & 30 & 2 & 96.88 & 2 & 1.94 & Agreeing & 24.5 \\
\hline \multirow[t]{3}{*}{$33 / 3$} & \multirow{3}{*}{$\begin{array}{l}\text { Enabling all groups, specially } \\
\text { youth in economic movement in } \\
\text { conformity with anti deviated } \\
\text { behaviors in community }\end{array}$} & $\begin{array}{l}\text { Supreme and } \\
\text { middle }\end{array}$ & 12 & 2 & 92.86 & 6 & 1.86 & Agreeing & \multirow[t]{2}{*}{0.84} \\
\hline & & Executive & 13 & 5 & 86.11 & 7 & 1.72 & Agreeing & \\
\hline & & Total sample & 25 & 7 & 89.06 & 8 & 1.78 & Agreeing & 10.13 \\
\hline \multirow[t]{3}{*}{$33 / 4$} & \multirow{3}{*}{$\begin{array}{l}\text { Availing new opportunities for } \\
\text { entrepreneurship internationally } \\
\text { and locally to know other countries } \\
\text { requirements in entrepreneurship }\end{array}$} & $\begin{array}{c}\text { Supreme and } \\
\text { middle }\end{array}$ & 9 & 5 & 82.14 & 10 & 1.64 & Agreeing & \multirow[t]{2}{*}{0.03} \\
\hline & & Executive & 11 & 7 & 80.56 & 10 & 1.61 & Agreeing & \\
\hline & & Total sample & 20 & 12 & 81.25 & 10 & 1.63 & Agreeing & 2 \\
\hline \multirow[t]{3}{*}{$33 / 5$} & \multirow{3}{*}{$\begin{array}{l}\text { Providing economic and social } \\
\text { safety and security to the next } \\
\text { generation according to the } \\
\text { Egyptian Vision } 2030\end{array}$} & $\begin{array}{l}\text { Supreme and } \\
\text { middle }\end{array}$ & 14 & 0 & 100 & 1 & 2 & Agreeing & \multirow[t]{2}{*}{3.56} \\
\hline & & Executive & 14 & 4 & 88.89 & 5 & 1.78 & Agreeing & \\
\hline & & Total sample & 28 & 4 & 93.75 & 3 & 1.88 & Agreeing & 18 \\
\hline \multirow[t]{3}{*}{$33 / 6$} & Investing investment projects' & $\begin{array}{l}\text { Supreme and } \\
\text { middle }\end{array}$ & 11 & 3 & 89.29 & 8 & 1.79 & $\overline{\text { Agreeing }}$ & 0.17 \\
\hline & returns in creating the state infra & Executive & 13 & 5 & 86.11 & 7 & 1.72 & Agreeing & \\
\hline & structure & Total sample & 24 & 8 & 87.5 & 9 & 1.75 & Agreeing & 8 \\
\hline
\end{tabular}

Value of $\mathrm{Ca}^{2}(1,0.05)=3.841, \mathrm{Ca}^{2}(2,0.05)=5.991$

Arithmetic mean: disagreeing (1: 1.5), agreeing (2: 1.6)

From table number (11), there are no statistical significant differences between the research sample's responses about the third factor's statement as value of the calculated $\left(\mathrm{Ca}^{2}\right)$ was less than its tabular value at level $(0.05)$ and ranged between $(0.03: 3.56)$ with an outweighed percentage between $(81.25: 98.44)$

According to the whole research sample's opinion, statements number $(32,33 / 2,33 / 1)$ toped their opinions with an outweighed percentage between $(93.75: 98.44)$ indicating 
reaching new entrepreneurial projects useful for executing the permanent development mechanisms.

Results of study of Khalid Salah (2016) (14), Mohamed Ibrahim Elmadhoun, Mona Radwan Elnakhala (2017) (18) agreed upon that business incubators play a great role in availing permanent projects and researches for researchers, increasing job opportunities and dealing with unemployment, developing community.

As statements number $(33 / 3,33 / 6,33 / 4)$ took the last place with an outweighed percentage (81.25: 89.09) on that entrepreneurial projects enable different groups specially youth to join economic development.

Results of study of Ibrahim Soliman Elmasry (2019) (12) show a relationship between entrepreneurial projects and business incubators as incubators are a prepared place of hosting entrepreneurs' projects.

\section{Conclusions:}

- Availing an investment work environment to facilitate administrative, financial and consultative works for entrepreneurs.

- Investing in scientific research by encouraging researchers on focusing on applied research and converting them to practical application stage to contribute to economic development.

- Business incubators provide legal support to incubated projects via availing legal services to establish and manage incubated projects.

- Verifying the feasibility of incubating the project and evaluating its success potential via carrying out the project' feasibility study.

- Effective coordination with governmental authorities and ministry of planning to obtain financial support for entrepreneurial projects.

- The incubators avail all facilities and services needed by the project.

- Ministry of youth and sports are directed towards establishing business incubators to adopt entrepreneurial projects via adopting and supporting culture of entrepreneurship.

- Entrepreneurial projects contribute to increasing the total state national projects' product and increasing the individual's income.

\section{Recommendations:}

Under the research conclusions, the researcher recommends taking the following procedures by ministry of youth and sports: 
- Establishing business incubators related to ministry of youth and sports and assigning them as unique experts to appoint individuals and human cadres able to promoting entrepreneurship and provide advice to entrepreneurial projects compilers.

- Concluding a cooperation protocol between ministry of youth and sports and research organization to link the ministry to the university as well as industrial and service companies and businessmen.

- Establishing an information bank and surveying small projects completely and knowing their products and market shares to create a supporting environment for these projects.

- Following a scientific methodology to select creative ideas and converting them to incubated projects.

- Creating new administrative unit competent for following up the incubated projects to understand their nature as well as difficulties they may face and how to overcome.

\section{Bibliography}

First: Arab Bibliography:

1 Abdelmawgoud Abdalla, Kossay : : The Role of Business Incubators in Supporting Marketing Sary Aref (2016) Knowledge for Small and Middle Size Projects at Tabok, a thesis published on the magazine, Saleh Abdalla Center for Islamic Economy, AL Azhar University, volume (19), issue (59). 
2 Adnan Hussein, Raed Khedr Abbas (2014)

3 Ahmed Ibn Abdelrahman Elshamimry, Sorour Aly Ibrahim Sorour (2014)

4 Alaa Elgharabawy, Mohmaed Mounir, Mohamed Elsalamy, Aliaa Mahmoud (2018)

5 Amr Alaa Zidan (2007)

6 Anwar Ahmed Elazzam (2009)

7 Bassem Tarek Eldilimy (2019)

8 Hassan Ahmed Elshafaey, Mohamed Khalil Aly, Marwa Farghaly Gaber (2017)

9 Hayat Bakirat (2017)

10 Hussein Alian Elharamsha (2014)

11 Hussein Farag Elshtewy (2015)

12 Ibrahim Soliman Elmasry (2019)
: The Role of Business Incubators in Developing Small Projects, Al Ayam Publishing House, Oman.

: Business Incubators: Concepts and Applications in Cognitive Economics, King Saud University, Riyadh

: Entrepreneurship and Small Projects, University Education House, Alexandria.

: Entrepreneurship: Motive Force of National Economies, Arab Organization for Administrative Development, Cairo

: The Effect of Using Business Incubators in Entrepreneurial Projects Success in Jordon, an un published doctorate thesis, Faculty of Administrative Studies, Amman Arab university, Jordon

: The Effect of Transitional Leadership on Achieving Entrepreneurship, a field study at national Iraqi faculties, an un published master thesis, Faculty of Economics and Administrative Sciences, Al al-Bay University, Jordon.

: Factors Affecting Creative Entrepreneurial Investment Projects at Sports Organization, a thesis published on Faculty of Applications of Sports sciences, issue( ), volume ( ), December, Faculty of Physical Education for Boys, Alexandria.

: The Role of Business Incubators in Small Organizations Growth, a case study, a non published master thesis, Faculty of Economic and Commercial Sciences, Kasidi Mirbah University, Algeria.

: The Role of Business Incubators in Finding and Developing Entrepreneurial Technological Projects in Jordon, a thesis published on Al Zarkaa Magazine for Human Research and Studies, volume (14), issue (2), Jordon.

: The Role of Technological Incubators in Achieving Cognitive Economics via Transferring Creative Ideas to Wealth, the Arab Forum of Enhancing the Role of Industrial and Technological Incubators in Industrial Development, Ministry of Industry, Tripoli.

The Most Important Roles Affecting the Ability of Emerging Companies to Administrative Creation in Business Incubators, 
13 Ghada Ibrahim Hanafy (2017)

14 Khalid Salah Hanafy Mahmoud (2016)

15 Magda Soliman Artima (2012)

16 Mahmoud Nehmedo Aly (2016)

17 Malden Mosleh Elkayal (2017)

18 Mohamed Ibrahim Elmadhoun, Mona Radwan Elnakhala (2017)

19 Mona Radwan Elnakhala (2012)

20 Omran Mohamed Elfawaz (2014) and Technology, Islamic University, Gaza, a non published master thesis, Faculty of Economics and Administrative Sciences, Islamic University, Palestine.

: A Suggested Frame for Developing Small Size Projects Incubators Experience in Egypt: An Analytical Study Compared to Successful Experiences for Some Countries, a research published on Commercial Research Magazine, Faculty of Commerce, Zagazig University, issue 2, volume 39

: Technological Incubators as Mechanisms of Linking Universities to Production Sectors in the Field of Scientific Research and Community Service : an Analytical Study of Opinions of Teaching Staff Members at Egyptian Universities, a thesis published on Arab Universities Union Magazine for High Education Research, issue (1), volume ( 36), the country

: Business Incubators and their Role in Creating Competitive Capacities for Small Projects, an unpublished doctorate thesis, Faculty of Business, Oman Arab University, Jordon.

The Role of Small and Middle Projects in Egyptian Economy 2015, a research published on magazine of economics and political science, issue (2), volume (7), July, Cairo university.

: The Role of Business Incubators in Achieving Permanent Capacities - a Field Study in Small Projects in Civil Community Organizations in Jordanian Nomadic Life, an unpublished master thesis, Faculty of Finance and Business Administration, Al al-Bayet University, Jordon.

The Fact of Technological Incubators and their Role in Developing Projects in Gaza, a Comparative Study between Technology Incubator in Islamic University and University Faculty, a thesis published on Islamic University Magazine, issue (3), volume (25), Gaza.

The Fact of Business Incubators and their Role in Supporting Small Projects for Youth in Gaza, a thesis published at Conference of Youth and Development in Palestine, Fourth Conference, Islamic University, Palestine.

: The Fact of Business Incubators and their Role in Supporting Small Projects for Youth of Gaza, an unpublished master 
21 Osama Ibn Sadik Taib, Mohamed Nour Ibn Yassin, Essam Ibn Yahia Elfalaly (2006)

22 Rima Mohamed Aly Masoud (2005)

23 Rond Khalid Elmallah (2015)

24 Rowad 2030 (2019)

25 Soha Hamzawy (2008) thesis, Faculty of Economics and Administrative Sciences, Yarmouk University, Jordon

: Towards Cognitive Community: Business Incubators, Research and Consultation Institute, King Fahd National Publishing House.

: The Effect of Business Incubators in Employers' Forum for Women's Productive Projects, an unpublished master thesis, Faculty of Post Graduate Studies, Jordanian University, Jordon.

: The Critical Factors of Incubated Projects Success in Jordon a field study, an unpublished master thesis, Faculty of Economics and Administrative Sciences, Yarmok University, Jordon.

: Ministry of Planning and Administrative Reform, first issue, January.

: Initiations of Cooperation between Organizations and Universities to Create Technological Potentials under Economy Depending on Knowledge, a thesis published on $\mathrm{Al}$ Basira Centre Magazine for Educational Research, Consultation and Service, issue (10), Algeria.

\section{Second: Foreign references}

26 Corinne Colbert (2010),

: Best practices in action: guidelines for implementing firstclass business incubation programs, Publisher: Saline, MI: NBIA Publications

Contemporary Entrepreneurship: Multidisciplinary Perspectives on Innovation and Growth, Springer; 1st Edition Marcus Dejardin, Domingo Garcia Pérez de Lema (2016),

28 George Watt, Howard Abrams (2018)
: Lean Entrepreneurship: Innovation in the Modern Enterprise, Apress; 1st Edition 
29 Joffy George (2017)

30 Jobe Leonard (2014),

31 Louis G Tornatzky; Hugh Sherman; Dinah Adkins (2003)

32 Mark Long (2019),

33 Otto Chui Chau Lin (2018),

34 Sameer Khandekar ,B. V. Phani (2017)
: CORPORATE INCUBATORS: EMERGING TREND FOR ENTREPRENEURSHIP, MASTERS; 1 edition

Startup Incubators and Business Accelerators: The Easy Way to Create a Startup Incubation and Business Acceleration Center, Books 180 pages

Incubating technology business: a national benchmarking study, Publisher: Athens (OH) : NBIA Publications, cop

: Facilities Management for Business Incubators, Independently published

: Innovation and Entrepreneurship: Choice and Challenge, World Scientific Publishing Company

: Innovation, Incubation and Entrepreneurship: Case Studies from IIT Kanpur, Springer; 1st ed. 71 pages

\section{Third: Internet Web Sites}

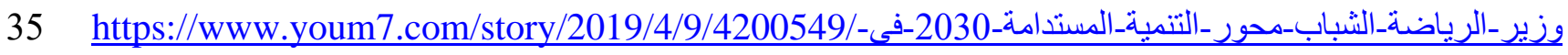

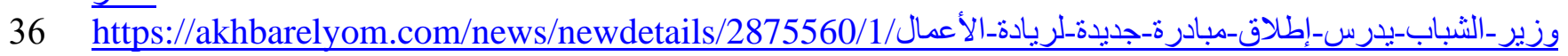

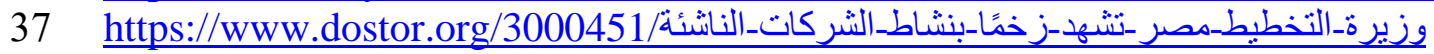

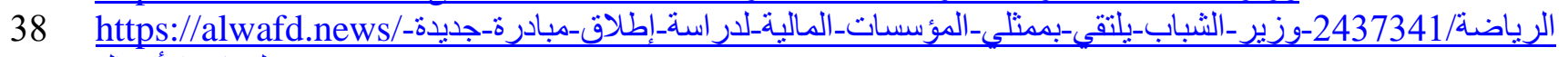
لريادة-الأعمال 